\title{
EXILE, LANGUAGE, AND TRAUMA IN RECENT AUTOBIOGRAPHICAL WRITING BY JORGE SEMPRUN
}

In L'Écriture du désastre (1980), Maurice Blanchot writes: 'qui écrit est en exil de l'écriture: là est sa patrie où il n'est pas prophète'. ${ }^{\mathrm{I}}$ Here, the writer does not inhabit writing but exists in an impersonal relationship of deathly exile to the text. In Jorge Semprun's writing, exile is explored on multiple levels: linguistic, geographical, political, and ethical. In this discussion, one aspect of Semprun's representation of exile will be explored, namely his relationship to language and writing, with reference to three recent autobiographical texts: L'Écriture ou la vie (1 994), Adieu, vive clarté ... (1 998), and Le Mort qu'il faut (2001). Two of these, L'Écriture ou la vie and Le Mort qu'il faut, are literary testimonies which focus on Semprun's experiences in Buchenwald concentration camp, where he was imprisoned from I 944 to I 945 after his arrest in late 1943 for his work in the Communist Resistance. Adieu, vive clarté ..., however, is a highly literary memoir of his early life and arrival in Paris in I939 as an exile from Franco's Spain and, according to Semprun, is unrelated to his Buchenwald experiences:

Ce livre est le récit de la découverte de l'adolescence et de l'exil, des mystères de Paris, du monde, de la féminité. Aussi, surtout sans doute, de l'appropriation de la langue française. L'expérience de Buchenwald n'y est pour rien, n’y porte aucune ombre. Aucune lumière non plus. Voilà pourquoi, en écrivant Adieu, vive clarté . . ., il m’a semblé retrouver une liberté perdue, comme si je m’arrachais à la suite de hasards et de choix qui ont fini par me composer une sorte de destin. ${ }^{2}$

Having by this point in his career written and spoken extensively about his experience as a Buchenwald deportee in fiction, autobiography, press articles, and interviews, it is understandable that in Adieu, vive clarté ... Semprun might wish to revert to writing a Bildungsroman concerning a period of relative existential freedom, his discovery of Paris à la Rastignac and his love of world literature and languages. However, it will be argued that the traumatic quality of his exile represented in Adieu, vive clarté . . . is fundamentally linked to the formal aesthetics of his Buchenwald testimonies and to the staging of a melancholic patriarchal masculinity in his writing. Distancing himself from his Buchenwald experience, Semprun's representation of his adolescence and early adulthood in Adieu involves a circumnavigation of earlier experiences of loss, specifically those constituted by the death of his mother in 1932 and the family's exile from Franco's Spain in September 1936. The impact of these losses is crucial to the autobiographical narrating subject's relationship to language and writing because they establish a traumatized relationship to the Symbolic within a largely francophone autobiographical space. Hence Spanish, Semprun's 'langue maternelle', is abjected in a Kristevan sense as a symbolic system that threatens the integrity of the francophone subject in favour of French, which he adopts from the writing of Le Grand Voyage ( 1963 ) onwards to relate

\footnotetext{
I Blanchot, L'Écriture du désastre (Paris: Gallimard, I980), p. I05.

2 Jorge Semprun, Adieu, vive clarté . . . (ı 998; Paris: Gallimard, 2000), p. ıо ; hereafter referenced in the main text as $A V C$.
}

Modern Language Review, I03 (2008), 697-7 I4

(C) Modern Humanities Research Association 2008 


\section{$698 \quad$ Autobiographical Writing by Forge Semprun}

his experiences of exile and Buchenwald. Before examining the importance of exile and Buchenwald in Semprun's bilingual relationship to writing, it is first necessary to address the role of gender and maternal loss in the construction of the Semprunian speaking subject.

In this exiled identity constructed in French, Semprun's relationship to gender is complex, predicated as it is on maternal loss and the confrontation with his own alterity, first as an exile in France and second as a prisoner in Buchenwald. Interestingly, in his presentation of Adieu cited above, Semprun specifically indicates gender as an aspect of his exile Bildungsroman: in addition to discovering a 'nouvelle patrie', he also embarks upon 'la découverte [. . . ] des mystères [. . .] de la féminité'. When Semprun was forced to abandon Spain, his 'mother' country, because of his political affiliation, certain aspects of his identity travelled with him: his aristocratic background and privilege as a diplomat's son, his multilingualism, his cultural capital and political affiliation. Semprun as an exiled subject is not gender-neutral: in his exile from Spain to France, from one patriarchal society to another, he migrates within spaces governed by the phallogocentric economy that facilitates his acquisition of symbolic power and validates his claim to seek refuge in the universal. Indeed, such symbolic power is predicated, as we shall see, on the melancholic abjection of the maternal and the feminine in his writing, which effectively genders his turn to the universal and, more specifically, to French republican universalism. His 'appropriation' of the French language as a 'nouvelle patrie' that facilitates his 'enracinement dans l'universel' is contingent upon the abjection of the feminine as a 'particularisme' ( $A V C$, p. I 49). The narrator of Adieu demonstrates that he is not unaware of the gender-political ramifications of his stance but disregards contemporary feminist critiques of masculinist language which conflates the masculine with the universal in terms such as 'droits de l'homme' ( $A V C$, p. 1 27). He explains his usage of the masculine form of the noun 'inconnu/e'-in the context of a discussion concerning the shared appreciation of Gide's Paludes ( 1895 ) with an 'inconnu'-saying that he has never had the good fortune to seduce a blonde 'inconnue' by murmuring a few lines from Gide's text $\left(A V C\right.$, p. I 27) ${ }^{3}$ Hence, his speaking position in this instance is predicated on the silencing of the female subject as other whose difference is appropriated into the masculine universal or in relation to the (absent) female 'inconnue' as a figure of fantasy to be seduced into 'une aventure' by the deployment of his cultural capital.

This willed patriarchal blindness to the political ramifications of linguistic pragmatics is compounded by the representation of gender and sexuality elsewhere in Semprun's writing: women feature rarely and when they do, it is predominantly as the erotic object of the patriarchal heterosexual male gaze or as an idealized mother figure. In Adieu, several further examples could be cited, such as when the narrator observes a francophone woman admiring the 'floriture' on a bright salmon-pink girdle in the window of a lingerie shop in The Hague $(A V C$, pp. 6o-6r). Interestingly, her malapropism (substituting 'floriture' for 'garniture'), which he notes, is juxtaposed with his discovery of

\footnotetext{
3 André Gide, Paludes (Paris: Gallimard, 1973).
} 
'des femmes galantes' and the beauty of Baudelaire's Les Fleurs du mal. Later, the narrator recalls observing a bourgeoise making love with a worker on a métro train, which he elaborates into a fantasy recalling Joseph Kessel's i 928 novel Belle de jour, which concerns a woman who leads a double life as a prostitute ( $A V C$, pp. I88-9i). Unable to speak to his prudish father about sexuality, in Adieu the young Semprun is depicted as acquiring his knowledge of women though patriarchal literary stereotypes, female nudes in the Prado museum, or the vulgar gossip of his school friends. Women such as Hélène, a shipowner's wife whom the narrator also associates with the lead character of Belle de jour and with whom he has one of his first sexual encounters in I939 in Biriatou in France, are represented as eroticized maternal figures $(A V C$, pp. 245-63). Ironically, meeting her again by chance ten years later, the narrator tries to catch her eye but her gaze is 'brouillé, quelque peu éteint' and she has forgotten him and their personal involvement despite recognizing 'la masculinité de [s]on regard' ( $A V C$, p. 26r).

The patriarchal speaking-subject position, enacted through this sexually objectifying gaze and the silencing of women, is nevertheless rendered fragile by its self-disembodiment and self-silencing in the text. Sexuality appears dematerialized and reduced to a disembodied gaze. This absence of the body from the text seems related in part, as María Angélica Semilla Durán has argued, to the representation of maternal loss in Semprun's writing. ${ }^{4}$ I contend further that it is related to the bilingual, trauma-marked aesthetics of his writing which disperse the speaking subject across languages, and configures the body as Buchenwald victim, as moribund and de-eroticized, dead or absent. Hence a discursive connection can be proposed in Semprun's writing between the representation of the dead mother's body and the representation of the dying or disembodied other self categorized as the 'musulman' in the concentration camps, which would establish a link between Adieu and his Buchenwald writing. To examine the validity of this connection, the representation of the mother in Adieu, vive clarté . . . needs to be examined.

Fictional representations and recurrent associations with Susana Maura, Semprun's mother, appear in his writing from i 969. Yet it is not until Adieu that she is evoked at any length in a somewhat Proustian autobiographical presentation and, as in the representation of death in his concentration-camp writings, the event of her death is elided. Susana Maura died in July r 932 of septicaemia when Semprun was eight years old. After her death, her bedroom-previously a place of erotic fascination and enchantment for Semprun as a young 'Marcel'was locked up until his father's remarriage. In several of his texts, including Adieu, this 'chambre conjugale et mortuaire' $(A V C$, p. $5 \mathrm{I})$ is represented. Located at the end of a long corridor in the family's apartment in Madrid, the bedroom which was once a privileged space of sensuous maternal encounter becomes a space of loss; a space where desire dies and death lives. In Adieu, the mother is evoked in dead space-in the common autobiographical device of the photograph or as an absent presence in the 'chambre mortuaire' at the end of the corridor ( $A V C$, pp. 45-46). The corridor is hence doubly signified

${ }^{4}$ Le Masque et le masqué: Forge Semprún et les abîmes de la mémoire (Toulouse: Presses Universitaires du Mirail, 2005), pp. I 92-2 I 2. 
as a birth canal leading back to a pre-Oedipal encounter with the mother and to life, and a corridor leading to death, a spatial metaphor for 'le grand voyage' to Buchenwald. The narrator refers to the only photograph of his mother he possesses, taken in I920-three years before Semprun's birth-at a dinner of the Spanish Academy, presided over by his grandfather. She is surrounded by male academicians, and her gaze appears dark, deathly, as if she already belongs to the 'chambre mortuaire'. It suggests the extinguished gaze of the 'musulman' evoked in Semprun's Buchenwald writings as well as the 'regard brouillé, quelque peu éteint' of his former lover who fails to remember him in a ricochet effect of traumatic loss in which his writing can never wrench itself from the lived experience of dying and death, can never really say anything else.

To palliate the traumatic resonance of this dead space of the m/other, another space from the Madrid family apartment is invoked in Adieu, namely the paternal library, which, as Durán notes, is a complex symbolic space. ${ }^{5}$ It is a spatial legacy as the father bequeaths his poetic vocation to his son, yet the library will later provide him with a means of survival in Buchenwald, a literal way of entering into dialogue with the other, removed from his experience of the other's dying and death. The library in Semprun's writing is represented as a Borgesian 'Library of Babel': eternal, multilingual, total, evoking living and dying in myriad texts which fall into and out of coherence according to their reception. Post-exile, only one book will survive from the paternal library: Marx's Das Kapital, which will provide Semprun with his ideological compass-point until his expulsion from the Communist Party in ro64 $(A V C$, p. 49). Consequently, the representation of the maternal and paternal imagos in Adieu is crucial to the establishment of the Semprunian speaking subject, entailing that the mother is associated both with sensuality and life but also with silence, dead space, and an extinguished desire-less gaze (a non-subject), whereas the father is aligned with the Symbolic: multilingualism, knowledge, and culture.

Durán has argued that Semprun's earlier descents into his concentration camp experience constituted by Le Grand Voyage ( 1963), Quel beau dimanche! ( I980), and L'Écriture ou la vie (1994) facilitate his attempt in Adieu to relate an earlier period in his life before the Fall and the confrontation with 'le Mal absolu' - as if he believes it is possible to suspend memory. ${ }^{6} \mathrm{I}$ am contending here, however, that there is a reciprocal interference between the Lebenswelt of loss and exile represented in Adieu and Semprun's Buchenwald testimonies, functioning as two forms of radical and traumatic displacement, predicated on loss. Both, to differing degrees, constitute distinct encounters with his own alterity for the Semprunian narrating subject. Contra Semprun's presentation of Adieu cited above, then, it will be argued that Adieu sheds important light on the aesthetic, linguistic, and ethical aspects of his concentration-camp testimonies.

Before considering Adieu and Semprun's multilingualism further, we need to consider how traumatic experience might be represented in autobiography. If, as Shoshana Felman noted back in I 992, we live in 'an age of testimony', marked

Le Masque et le masqué, pp. 191-93.

6 Ibid., p. Io. 
by the Holocaust, Hiroshima, and Vietnam, ${ }^{7}$ then it can be argued that we live in an age of trauma seeking expression and one in which the politics and ethics of memory are highly contested. This is particularly the case for the memorial legacies of the Franco era in Spain and the French and German experiences of the Second World War to which Semprun bears witness in his autobiographical writing. Ulrich Baer has described trauma as 'unresolved experience' which is incommensurate with and irreducible to the symbolic forms available at a particular time. ${ }^{8}$ Baer argues that the traumatic experience is irreducibly other in its singularity. Moreover, he notes that "trauma" is not a stable term [. . . ] not because of the event's inherent content, but because recourse to an external frame of reference is unavailable'. ${ }^{9}$ According to this view, the experience of trauma is elusive and highly resistant to memorial inscription and integration and hence representation.

Nevertheless, this does not necessarily mean that trauma perpetually falls beyond representation. Theodor Adorno's much-cited statement of I 949 that 'to write poetry after Auschwitz is barbaric' was indeed modified by his subsequent acknowledgement that 'suffering-what Hegel called the awareness of affliction-also demands the continued existence of the very art it forbids; hardly anywhere else does suffering still find its own voice, a consolation that does not immediately betray it'. ${ }^{\circ}$ Moreover, as Susan Rubin Suleiman argues in connection with Holocaust writing, 'if a thing is spoken about, however obliquely, then it is not unspeakable-on the contrary, it may be the object about and around which one can never stop speaking'. ${ }^{\text {II }}$ This suggests that cultural practitioners such as Semprun have a crucial role to play in the elaboration of a poetics of trauma and the representation of the interrupted and unresolved quality of its experience. The trace of its halting journey through the psyche is likely to mobilize elements of temporal dislocation, absence, silence, and the deferral and repetition of experience that challenges or bypasses familiar symbolic forms. What this might constitute, however, is particular to the artist or writer, the experience at stake, and the form of its reception. It is a question, as Leigh Gilmore argues, of becoming attentive to the context and formulations of trauma and how autobiographers deviate from recognizable autobiographical forms in their project of representing the self and representing trauma. ${ }^{2}$

In the reception of trauma, the reader may encounter the limits of her or his understanding and empathy and be unable to decipher what Edmond Jabès,

7 'Education and Crisis, or the Vicissitudes of Teaching', in Testimony: Crises of Witnessing in Literature, Psychoanalysis, and History, ed. by Shoshana Felman and Dori Laub (New York and London: Routledge, I 992), pp. I-56 (p. 53).

8 Remnants of Song: Trauma and the Experience of Modernity in Charles Baudelaire and Paul

Celan (Stanford, CA: Stanford University Press, 2000), p. I

9 Ibid., p. 9.

10 'Cultural Criticism and Society' ( 1949$)$, repr. in The Holocaust: Theoretical Readings, ed. by Neil Levi and Michael Rothberg (Edinburgh: Edinburgh University Press, 2003), pp. 280-8I (p. 28I ); 'Commitment' ( I 974), in Notes to Literature, ed. by Rolf Tiedemann, trans. by Shierry Weber Nicholsen, 2 vols (New York and Oxford: Columbia University Press, I 992), II, 76-94 (p. 88).

I Crises of Memory and the Second World War (Cambridge, MA, and London: Harvard University Press, 2006), p. I 88.

${ }^{\prime 2}$ The Limits of Autobiography: Trauma and Testimony (Ithaca, NY, and London: Cornell University Press, 200I), p. 7. 
an important theorist of exile and alterity, has described as a form of 'écriture blanche' that exists beyond the sign itself. ${ }^{13}$ As he observes, 'ce n'est pas le mot écrit, mais le mot effacé dans le mot, qui nous efface. Le livre nous donne à lire ces deux effacements. ${ }^{14}$ Erasure, hiatus, and loss are central to Jabès's notions of alterity, subjectivity, and the wound of writing in a post-Shoah landscape in which writer and reader are engaged in an infinite act of writing and reading self-erasure and loss. The extent to which the reader's encounter with trauma can occur at all is related to the degree to which she or he can enter into a compassionate and empathetic relationship with alterity and suffering, given the impossibility of occupying the precise position of the trauma sufferer. In this way the reader may offer a space of reception for the interrupted symbolization of trauma to occur. As one of the Buchenwald prisoners says in Semprun's L'Écriture ou la vie, 'Le vrai problème n'est pas de raconter, quelles qu'en soient les difficultés. C'est d'écouter . . . Voudra-t-on écouter nos histoires, même si elles sont bien racontées?'15

In the case of autobiographical writing, it shares characteristics with the writing of trauma in that it similarly works to give voice to an absent other, the past other self which, for the subversive singularity of its experience to be received, requires a hospitality to difference on the part of the present-day narrator and reader. This involves a relinquishing of preoccupations with egoic ontology, authority, and identification at the heart of the Western autobiographical tradition. As Blanchot observes in L'Écriture du désastre, writing one's autobiography is a quest for survival by perpetual suicide, as one entrusts what one was to the hospitality of the reader as other. ${ }^{16}$ In this sense it is an exchange of alterity between autobiographer and reader. In Holocaust autobiography, the writer works with radical ruptures of time, selfhood, and the interrupted registration of traumatic experience. The 'unresolved' character of the experience which the writing of autobiography cannot remedy poses an ethical challenge to the reader- to respect the alterity of its form and content. Moreover, the traditional constraints associated with the autobiographical genre-that there might be identity of author, narrator, and character and that a claim of historical truth is made for the events and people represented-may become renegotiated in an autobiographical pact with the reader entailing a 'devoir de mémoire' which is both painful and ethically performative. ${ }^{17}$

In Semprun's case, the autobiographer's quest for survival by perpetual suicide, of which Blanchot speaks, assumes altered significance. Semprun's survival is structured and signified by genocide as a form of perpetual suicide in his experience of 'passing through' the deaths of others in Buchenwald. ${ }^{18}$ Qua

\footnotetext{
${ }^{1}$ Du désert au livre: entretiens avec Marcel Cohen (Paris: Belfond, I 980), pp. 74-75.

${ }^{14}$ Un étranger avec, sous le bras, un livre de petit format (Paris: Gallimard, I 989), p. 37

${ }^{15}$ Jorge Semprun, L'Écriture ou la vie (Paris: Gallimard, I 994), p. I34; hereafter referenced in the main text as $\dot{E} V$.

${ }^{16}$ L'Écriture du désastre, p. I 05.

${ }^{17}$ The term 'autobiographical pact' is taken from Philippe Lejeune, Le Pacte autobiographique (Paris: Seuil, I 975).

${ }^{18}$ Semprun has described his experience in Buchenwald as 'une traversée de la mort'; see Magazine Littéraire, 3 I 7 (January I 994), I 02. For further discussion of the autothanatographical aspects of Semprun's Buchenwald writings, see my 'The Infinity of Testimony and Dying in
} 
autothanatography as Jacques Derrida and Louis Marin have explored the term, Semprun's texts challenge generic assumptions concerning autobiography ${ }^{19}$ In common with other concentration-camp testimonies which, as Reiter argues, are 'an attempt to master an exceptional threat to the personality and life of the individual $[\ldots]$ and lay the basis for a meaningful further existence', Semprun's texts circumnavigate the unknowable experience of death as an encounter with alterity which continues to erupt into the narratorial consciousness long after the liberation from Buchenwald. ${ }^{20}$

The fragmented, multilingual representation of Semprun's Buchenwald experience both in autofictional and autobiographical texts with multiple analepses, prolepses, repeated episodes narrated differently, intertextual references, aliases, and surrogates suggests a creative, yet highly traumatized, engagement with writing, one which is rooted in his pre-Buchenwald experience of loss and exile, as evoked in Adieu. In Le Mort qu'il faut, when Semprun observes that he needs bilingual readers who take pleasure in reading both French and Spanish, he may not only be referring to his desire for a reader's Franco-Hispanic bilingual competence but also to that reader's ability to decipher the 'écriture blanche' of trauma, as another form of bilingualism. ${ }^{21}$ This 'other' bilingualism stages an ethical receptivity and world-view for another's suffering and is prepared to voice its protest against the world in which that suffering occurs.

In Adieu, the representation of Semprun's exile from Franco's Spain in 1936 when he was thirteen concerns his experiences of exclusion and displacement, triggering an obsession with acquiring a faultless competence in the French language and immense resources of French cultural capital. Semprun's exile from Spain to France and his immersion in the universalism of the French language prefigures his exile in Buchenwald and immersion in the lingua tertii imperii, as Victor Klemperer has termed the language of Nazism. ${ }^{22}$ In 1939 , immersion in the French language constitutes a means of dealing with the trauma of exile:

J'apprenais les langues étrangères, ce qui était une façon d'oublier, du moins de mitiger, les inquiétudes de l'exil. J'apprenais, en effet [.. .] que la patrie n'est pas un mot, mais les mots. Je découvrais alors la patrie du langage, au moment ou s'éloignait, s'estompait, le langage de la patrie. ${ }^{23}$

Henceforth, the multilingual Symbolic becomes Semprun's native land in

Jorge Semprun's Holocaust Autothanatographies', Forum for Modern Language Studies, 4I (2005), 407-17.

${ }_{\text {I9 }}$ See Jacques Derrida, Otobiographies: l'enseignement de Nietzsche et la politique du nom propre (Paris: Galilée, I984), and Louis Marin, L'Écriture de soi: Ignace de Loyola, Montaigne, Stendhal, Roland Barthes (Paris: Presses universitaires de France, I99 I)

${ }^{20}$ Andrea Reiter, Narrating the Holocaust (London and New York: Continuum, 2000), p. 57.

${ }^{21}$ Jorge Semprun, Le Mort qu'il faut (Paris: Gallimard, 200I), p. 79; hereafter referenced in the main text as $M F$.

${ }_{22}$ See The Language of the Third Reich, LTI-Lingua Tertii Imperii: A Philologist's Notebook ( I946), trans. by Martin Brady (London and New Brunswick: Athlone Press, 2000). I am grateful to my colleague Henry Phillips for alerting me to Klemperer's work.

${ }^{23}$ Semprun cited in Gérard de Cortanze, Forge Semprun: l'écriture de la vie (Paris: Gallimard, 2004), p. 47. 
which his experience is not reducible to a single linguistic form or correlative with a particular geographical space.

As a Bildungsroman, Adieu charts this altered relationship to the Symbolic in the fragmented representation of Semprun's memories of the beginning of his exile in France in I939. The text is divided into four parts comprising seven chapters, yet any ordering function this structure might have is undermined intratextually by the narrator's associative technique involving frequent prolepses and analepses. The narrator accepts that the reader might interpret such a method as an involuntary habit on his part, and claims that it is not a rhetorical strategy but a method of inscribing himself corporeally and mentally in Bergsonian 'durée' or inner psychological time-a form of personal temporal realism $(A V C$, p. 217). This exploded chronology, also a feature of Semprun's Buchenwald narratives, acts as a means of representing traumatic experience whereby historical time is suspended in favour of a subjective temporality anchored in the lived experience of 'l'instant'. It serves to shelter the narrator from the collective historical time of Buchenwald, where chronology led to annihilation. Travelling between fragments of 'l'instant', Semprun's narrative technique highlights what Derrida has referred to as 'the aporia of testimony', in the sense that appealing to the instantaneous as a 'stigme', a singular point in time, also entails an appeal to an exemplary instance in so far as it must be able to be repeated, translated: 'To the extent that it is repeatable, the singular instant becomes an ideal instant. ${ }^{24}$ In this way, the autobiographer testifies to the sharable and unsharable secret of what happened. In Semprun's fragmentary autothanatographical narration, 'l'instant' is 'en instance' or deferred, in abeyance, because it constantly implies the impossible necessity of death and stages the autobiographical subject as a Heideggerian 'being-for-death'. ${ }^{25}$

Semprun's fragmentary and often circular testimony to the other's death in Adieu, L'Écriture ou la vie, and Le Mort qu'il faut evokes the traumatic circumlocution discussed in Shoshana Felman's reading of Albert Camus's $L a$ Chute (1956) in Testimony (1992). ${ }^{26}$ Felman argues that La Chute can be read as an allegory of the crisis of witnessing produced by the Second World War and particularly by the Holocaust. In a complex circumlocutionary narration, La Chute is structured around but does not resolve the central question of how to survive witnessing the other's death. Buried in the middle of Camus's narrative is an episode in which the narrator becomes the chance witness of a woman's suicide as she jumps into the Seine. ${ }^{27}$ From that point on, one does not know, as Felman notes, whose Fall we are witnessing-that of the narrator, haunted by the episode and his ethical failure to respond, or that of the woman to her death. ${ }^{28}$ Or to borrow Primo Levi's terms: does the reader witness the fall of 'the drowned or the saved' or both ${ }^{29}$ Echoing the Camusian trope, committing suicide by throwing oneself into the Seine is referenced several

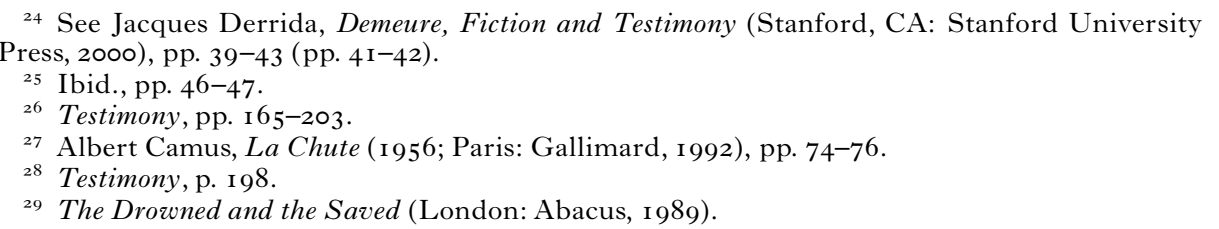


times in Semprun's texts: in his reference in L'Écriture ou la vie to the suicide by the same means in 1970 of the multilingual Romanian Holocaust poet Paul Celan, which is echoed by the suicide in the same circumstances of Juan Larréa, a character from Semprun's La Montagne blanche (1988) and one of Semprun's many aliases ( $E V$, pp. 300, 302).

The motif of the Camusian 'fall' is relevant for three further reasons, and in all three cases language is triggered in response to the 'fall': firstly, in L'Écriture ou la vie Semprun relates how he himself fell from a crowded Paris suburban train as it entered the station on 5 August 1945, the day before Hiroshima was destroyed (ÉV, pp. 222-24). He awoke some time later with a head injury and relates how he felt no sense of self or awareness of language; he was simply able to look. It is only when a pharmacist speaks to him that he recovers a sense of his existence: "je suis redevenu "moi" à cet instant précis, sous le regard attentif de cet homme' ( $E V$, pp. 224-25). He then suddenly remembers feeling similarly crushed on the train as it arrived at Buchenwald-a recollection which triggers his project to relate his Buchenwald memories ( $E V$, pp. 228-29). Several associations with 'the fall' are important in this passage: its link both to a genocidal event (Hiroshima) and to Semprun's 'rebirth'; its catalytic value as a trigger for his Buchenwald memories; the importance of the reciprocal gaze after the fall as a guarantor of his recovered existence and the decision to write about his memories as a response to the fall. Secondly, and also in L'Écriture ou la vie, the motif of the fall is again associated with Semprun's Buchenwald writing when he claims that he began writing L'Écriture ou la vie on I I April I 987, the day of Primo Levi's death occasioned by a (possibly suicidal) fall from a third-floor staircase in his apartment building in Turin $(E ́ V$, p. 24I). Incidentally, I I April is also the date of Buchenwald's liberation in I 945 and of the start of the I96 I war crimes trial of Adolf Eichmann, head of the Gestapo's office for Jewish affairs and hence an important date connected to the Holocaust. Thirdly, in Camus's La Chute language is again represented as a response to the 'fall' when Clamence's love of language and oratory is contrasted with the 'gorille' bartender who speaks only Dutch but is more usually mutely aggressive towards his multinational clientele, having apparently no knowledge of so-called civilized languages. ${ }^{30}$ Here, as in the example of Nimrod, the architect of the Tower of Babel encountered by Dante on the approach to the ninth circle of the Inferno, the dysfunction, misuse, and collapse of language is aligned with hell and a loss of civilization. ${ }^{31}$ In Semprun's writing, as in Camus's $L a$ Chute, language is a response to the 'fall' in its literal and metaphorical senses and is central to the ethical relation. Hence he employs multilingualism and intertextual allusion as an attempt to write against the disaster, by making space for alterity and for the potential re-establishment of multicultural civilization.

Semprun's writing hence maximizes the possibilities of linguistic, cultural, and generic hybridity, represented by the intercalation of poetry and prose, fiction and autobiography. In the case of discursive hybridity, Semprun has

$3^{\circ}$ La Chute, pp. 7-9.

${ }^{31}$ Dante, The Divine Comedy, I: Hell, xxxi. 77-8 I, trans. by Dorothy L. Sayers (Harmondsworth: Penguin, I 977), p. 267. For further examples of references to Dante in La Chute, see Adèle King, 'Structure and Meaning in La Chute', PMLA, 77 ( 1962), 660-67. 
described the importance of remembering and reciting poetry in Buchenwald as a means to 'se raccrocher à un univers autre que celui du camp' and 'la mémoire poétique' as a survival strategy which enabled him to withstand 'cette-nuit-là, allongé entre les mourants', described in Le Mort qu'il faut..$^{32}$ Poetic recitation is also a way of evoking the father, of re-establishing a relationship with the Symbolic in the 'univers concentrationnaire' in which language is abused as a genocidal tool. ${ }^{33}$ Semprun's citation of poetry in his Buchenwald writing allows him to universalize traumatic experience by clothing it in literary tropes and allusions, thereby demonstrating that poetry and Holocaust representation are not mutually exclusive. As Susan Gubar notes, citing Adrienne Rich: 'The resistance of verse to narrative closure and the attentiveness it fosters enhance its ability to "engage with states that themselves would deprive us of language and reduce us to passive sufferers".'34 Adieu, vive clarté..., as the final ellipsis of the title suggests, is cited from the second line of Baudelaire's 'Chant d'automne', which forms part of the 'Spleen et Idéal' section of Les Fleurs du mal ( I 857). A bipartite funereal poem, 'Chant d'automne' explores the poet's desire to savour life's fast-fading pleasures before winter brings death and the definitive loss of the ideal. Recalling Georges Perec's parenthetical ellipsis separating the two parts of $W$ ou le souvenir d'enfance (i 975), a partly allegorical reflection on his situation as a child of a mother who died in Auschwitz, the ellipsis in Semprun's title similarly suggests the absent presence of his Buchenwald experience and its traumatic resonance in the formal properties of the text. ${ }^{35}$ In Baudelaire's poem, the desires of the memorialist and the poet become fused: both wish to regress and capture an earlier happier experience to stave off a traumatizing immersion in suffering and dying. Similarly, Semprun's 'regression' to his adolescence in Adieu suggests a desire to escape his experience of dying and death in Buchenwald-what Derrida has termed in relation to Blanchot 'the unexperienced experience of death'; $3^{6}$ indeed, Semprun has claimed he is not a survivor, for no one at all survives the experience of the camps ( $E V$, pp. I 4950). Yet inevitably, in Adieu, the narrating 'je' speaks from a post-Buchenwald space, despite Semprun's claim to represent a life pre-Buchenwald and his non-chronological approach to autobiographical narration. Moreover, the title is ambiguous in that one is unsure at what point the 'clarte' is lost: is the text charting the period prior to or after the demise of life's pleasures? In a sense, it does both: 'clarté' is already definitively lost as Adieu was written many years after the death of Semprun's mother, his exile in France, and his internment in Buchenwald, and yet the displacement of his Buchenwald experience and his self-reinvention in exile suggests that the definitive loss of the ideal-the Fallis yet to come. Hence, Semprun's citation of poetry allows him to reclaim language and experience in his representation of exile and Buchenwald. His

\footnotetext{
${ }^{32}$ 'Rencontre avec Jorge Semprun, à l'occasion de la parution du Mort qu'il faut' 〈http://www. gallimard.fr/catalog/entretiens/o I0394I 2.htm $\rangle$ [accessed 26 October 2004].

33 David Rousset, L'Univers concentrationnaire (Paris: Minuit, I 965).

34 'Poetry and Holocaust Remembrance', in Teaching the Representation of the Holocaust, ed. by Marianne Hirsch and Irene Kacandes (New York: Modern Language Association of America, 2004), pp. 165-79 (pp. I66-67).

35 Perec, $W$ ou le souvenir d'enfance (Paris: Denoël, I 975).

${ }_{3} 6$ Demeure, p. 47.
} 
running citation of 'Chant d'automne' in Adieu and that of Baudelaire's 'Le voyage' in L'Écriture ou la vie at the deathbed of Maurice Halbwachs act as ways of palliating traumatic experience and of writing the 'Fall'.

Semprun's relationship to multilingualism as another form of discursive hybridity now needs to be examined more closely in terms of the elaboration of a poetics of autobiography as trauma. In Adieu the narrator recounts how language and literature played a major part in his childhood-Semprun's father was a poet, in addition to being sometime Spanish correspondent for Esprit, the left-wing Catholic review established in I932. It was assumed that Semprun would follow 'la tradition paternelle' and become a writer; his mother would regularly proclaim that he would either be a writer or President of Spain $(A V C$, pp. 20-2 I ). The narrator notes that history prevented him from becoming President (though he was Spanish Minister for Culture from i 988 to I99I), and he eventually became a writer after working as a translator. Allusions and quotations from world literature, history, and continental philosophy proliferate in Semprun's texts. As Cortanze has noted: 'Semprun pense par références. [. . . ] Chaque événement de la vie déclenche, en cascade, références culturelles et historiques.' 37 His childhood was also linguistically diverse: his native language is Spanish, but his father insisted that all his children learn German initially before learning French, because of the former language's relative complexity for speakers of Romance languages $(A V C, \mathrm{p} .62)$. Semprun's multilingual and multicultural background is related to the privileges of his aristocratic origins and to his position as the son of a diplomat and poet. However, his distinctive relationship to each of these languages is significant, as will be argued below, because of the importance of multilingualism in his writings and the representational possibilities and particular voids that this allows in the context of inevitable translation slippage. Moreover, multilingualism has specific implications and effects in the context of the translation and transmission of Semprun's Buchenwald experience in autobiography.

Multilingualism is common among exile, deportee, and Holocaust writers and is often the result of their displacement and a reason for their survival. Paul Celan is again a useful comparator here: born in 1920 in Romania to German-Jewish parents, Celan lost both of his parents in the Holocaust and was himself interned in a labour camp for eighteen months. He managed to escape extermination and finally settled in Paris in I948. Like Semprun, he worked as a translator, as he spoke German, English, French, and Russian and gained much acclaim as a poet prior to his suicide in I970. Interestingly, Celan did not abandon German, his native tongue, and when questioned by his biographer about his relationship to German, said that 'I do not believe in bilingualness in poetry [. . .] Poetry - that is the fateful uniqueness of language.' He added, 'Only in one's mother tongue can one express one's own truth. In a foreign language the poet lies. ${ }^{38}$ As Felman has argued, in Celan's case he struggles to annihilate his own annihilation in reinscribing his experience in German. ${ }^{39}$ Semprun's relationship to his native language of Spanish is inevitably rather

\footnotetext{
37 Forge Semprun, p. 95.

${ }_{38}$ Cited in Felman, Testimony, p. 26.

39 Ibid., p. 27.
} 
different as it does not inscribe his annihilation in the same way, although it is still a relationship rooted in traumatic loss-the loss of Spain and the loss of his mother. However, unlike Celan, he wrote about his concentration-camp experience in French rather than in Spanish. Nevertheless, Celan's comments raise relevant questions here about multilingualism, translation, and Holocaust testimony relating to the authenticity and authority of narratorial personas created in the 'foreign' language.

Commenting on his bilingualism in 1988 , Semprun described himself as follows: 'Je suis assez apatride. Bilingue, donc schizophrène, donc sans racines.' ${ }^{\circ}$ This suggests that as a multilingual exile who has discovered 'la patrie du langage' he takes refuge in the multilingual Symbolic rather than a geographical homeland. The forced departure of the Semprun family from Franco's Spain in I 936 provides crucial motives of survival and integration to Semprun's development of his multilingualism; as Jabès notes, 'l'exil est une excellente école de fraternité'. ${ }^{4}$ However, the necessity to reinvent himself in France linguistically and culturally entails a traumatic upheaval in his relationship to the Symbolic through which he becomes alienated from his native language. In a Freudian reading of Semprun's bilingualism, Durán has argued that the native language is usually used as an ego defence mechanism and the second language as the fragment against which the defence operates. ${ }^{42}$ However, in Semprun's case the relationship is inverted as Spanish becomes the language to be temporarily erased in order that the ego-in-exile can be constructed in French. Thereafter, the native language of Spanish becomes associated with loss, primary emotion, 'pulsions', and repressed traumatic experience-anything that threatens the integrity of the reconstituted ego. Semprun has described Spanish, his native language, as 'langue de mon enfance, maternelle, matricielle' ( $A V C$, p. I34). $\mathrm{He}$ claims that Spanish has always been integral to his self-expression, yet most of his literary writing, since the publication of his first book Le Grand Voyage, has been written in French and subsequently translated into Spanish. Exceptions written in Spanish include two volumes of political memoirs and a novel published in 2003, focusing on the Franco legacy in Spain. ${ }^{43}$ One of these memoirs, Federico Sánchez se despide de ustedes, was initially started in French and then resumed in Spanish only to be subsequently translated by Semprun into French in a slightly altered version. Conversely, during his writing career he started writing several of his novels in Spanish only to revert to French. ${ }^{44}$ It is significant, then, that Semprun seems to have written little that is directly autobiographical initially in Spanish. Several reasons can be advanced for his seeming reluctance to write autobiographically in his native language: first, a desire to differentiate his literary persona and writings from those of his father, who wrote in Spanish; second, a need to distance himself from his 'langue maternelle', the loss of his mother and of Spain, and to facilitate the construc-

$4^{\circ}$ Cortanze, Forge Semprun, p. 46

${ }^{4 I}$ Jabès, Un étranger, p. 52.

${ }^{42}$ Le Masque et le masqué, pp. 234-35.

43 Autobiografía de Federico Sánchez (Barcelona: Planeta, i 977); Federico Sánchez se despide de ustedes (Barcelona: Tusquets, I 993); Veinte años y un día (Barcelona: Tusquets, 2003).

44 Durán, Le Masque et le masqué, p. 2 I 4. 
tion of an alternative identity in exile; third, a distancing strategy to enable him to represent the trauma of his concentration-camp experience (which is the focus of most of his writings in French); fourth, the impact of early censorship of his writings in Spain. These are powerful reasons which result in the abjection of Spanish as a language in which to represent the traumas of exile and Buchenwald.

In Adieu, he reflects on his early choice to write in French and asserts that reconstituting his early life in the writing process made him realize that the appropriation of the French language had played a formative role in the development of his personality ( $A V C$, p. I35). If this is the case, it occurs through a traumatized relationship to his mother tongue and to his early childhood experience more generally. From a Lacanian perspective, acquisition of language via entry into the Symbolic is in any case traumatic; the speaking subject always speaks from a place of primal loss. In autobiography, that loss is foregrounded as the narrator constructs a narrative from traces of an irretrievable past. In Semprun's case, the losses are multiple and involve personal and ethico-political traumas beyond the originary trauma implicit in language acquisition and in autobiographical self-reconstruction. In 1994 he explained that the reasons why he had not written about his childhood were closely related to his editorial work on his father's books and his own relationship to his native language. ${ }^{45}$ This suggests that Spanish has a crucial relationship to his childhood imaginary. In practice, Spanish appears to be Semprun's chosen language to represent his Communist trajectory; hence it structures a space in which the personal is dissolved into the collective and the political. His native language becomes abjected in a Kristevan sense, as a symbolic system that threatens the integrity of the francophone subject..$^{4}$ Moreover, when Semprun's early texts were published in Spanish, they were censored by the Franco dictatorship because of his Communist activism. The Spanish edition of Le Grand Voyage was hence first published in Mexico and, ironically given its traumatic Buchenwald subjectmatter, the edition presented to Semprun by his Spanish publisher had blank pages $(E ́$, p. I 3 I $)$.

French constitutes, then, the language and culture of Semprun's ego reconstruction in exile and is also used by Semprun to represent his memories of Buchenwald. Early in Adieu, the narrator relates an incident in a Parisian boulangerie shortly after his arrival in France that spurred him on to acquire a faultless command of French. The young Semprun timidly asks for a croissant with a strong Spanish accent, to which the boulangère responds with a stream of anti-Spanish invectives to her shop full of customers ( $A V C$, p. 65). An incident of everyday racism, this episode constitutes one of Semprun's formative experiences of alterity which drive him to 'me fondre dans l'anonymat d'une prononciation correcte' $(A V C$, p. 87), to lose the aural markers of his Spanish difference. Interestingly, the narrator claims it occurred on the same day as the fall of Madrid to Franco's forces, hence it is represented as being associ-

\footnotetext{
45 'Pourquoicette absence? Je ne sais pas. Mon rapport à l'enfance est celui de mon rapport à une langue perdue puis retrouvée. Pendant très longtemps, je n'ai plus parlé espagnol' ('Jorge Semprun “Je n'ai été le ministre de personne"', Magazine Littéraire, 3 I 7 (January I 994), pp. 96-ı O2 (p. 96)).

${ }_{46}^{6}$ Julia Kristeva, Pouvoirs de l'horreur (Paris: Seuil, I980), pp. I2-I 3.
} 
ated with the temporary loss of his identity as a Republican Madrileño and his propulsion into a liminal existence as an exile. Anonymity and universalism play an important part in his appropriation of the French language. French is idealized as a 'nouvelle patrie sans aucune des horreurs du patriotisme' where he is '[enraciné] dans l'universel' $(A V C$, p. I 49). In the context of his Buchenwald experience, his desire to embrace anonymity and the universal might be viewed as a traumatic remainder of concentration-camp life in the desire for his difference to be erased-because in that place being singled out as different frequently resulted in death. However, as I have argued earlier in the context of gender identity, there is a certain cost to Semprun's refuge in the supposed universality of the French language and culture because it has patriarchal ramifications which cast women as other and as eroticized objects in the narrator's imaginary.

Semprun's sense of alienation as an exile is exacerbated by further incidents recounted in Adieu relating to his linguistic and cultural acquisition, such as his first contact with the French language being a poem by Victor Hugo with an anti-Moorish reference, and later, in Paris, an unfounded accusation of plagiarism by his French teacher at the prestigious lycée, Henri IV, 'berceau intellectuel' of much of the post-war French male intelligentsia (AVC, pp. 6263, I35-36). Since 'la longue nuit sans sommeil de l'exil' ( $A V C$, p. 68), the narrator observes that he has been left with a sense of existential lassitude and void: 'l'absence à moi-même, au monde, l'extrême fatigue de vivre qui m'a saisi à l'adolescence, dans la radicale étrangeté où j'avais été projeté' $(A V C, \mathrm{p} .67)$. The traces of Semprun's alterity in exile are hence never completely effaced by the rather frantic strategies of assimilation adopted, as if he never accedes to subjecthood ( $A V C$, pp. 67-68).

In Buchenwald, Semprun's multilingualism facilitates his survival. As the only German-speaking Spaniard, he understands and is able to converse in the language of the camp officials and can undertake higher-status administrative work in the records office that requires a command of German ( $E$ V p. 309). It enables him to use the library, recathecting with the paternal imago, to develop his knowledge of German philosophy and literature. His multilingualism permits him to cross language barriers and to form relationships with other prisoners, enabling a form of social survival enacted through language. As in his earlier experience as a Spanish exile in France evoked in Adieu, his multilingualism allows him to construct a surviving persona in the 'univers concentrationnaire'.

In Primo Levi's chapter on 'Communicating' in The Drowned and the Saved, he notes that knowing German was crucial: in Auschwitz, those who did not speak German died within the first ten to fifteen days. ${ }^{47}$ The 'Wortschatz' or lexical patrimony was the primary tool of survival in an environment where not knowing German meant consigning oneself immediately to a subhuman existence in which violence assumed the role of the lingua franca. For those who were able to master some rudimentary German-a 'crematorium Esperanto' as the Polish Holocaust writer Tadeusz Borowski terms it—some form of human

\footnotetext{
47 The Drowned, p. 72.
} 
relationship was possible. ${ }^{4}$ Levi explains that to accept the eclipse of the word signalled the approach of definitive indifference because once communication is impossible or lost, language dries up, thought ceases, and the prisoner enters a void that becomes an existential antechamber to death. ${ }^{49}$ Relegated to the ranks of silent abjection, the prisoner has no access to information, is no longer able to orient him- or herself, to avoid the worst work tasks or harsh treatment by the SS. The 'univers concentrationnaire' is a multilingual, multicultural environment and yet one in which linguistic and cultural difference is a random pretext for annihilation. The discursive space is governed by the German variant known as the language of the Third Reich, comprised of semantic shifters and barbarisms-what Levi describes as 'Lager jargon', which is surprisingly close to the jargon of the Soviet Gulags-a significant factor in the case of Buchenwald, which was successively Nazi concentration camp and Soviet Gulag. ${ }^{\circ}$ This is not the German of Goethe who, as Semprun ironically notes in L'Écriture ou la vie, spent most of his life in Weimar, the nearest town to Buchenwald..$^{1}$

However, Semprun's use of French rather than German to represent his Buchenwald memories allows him to transpose his experience into another linguistic and cultural field, thereby creating an alternative autobiographical space. Inhabiting the French language as an exile affords him a nomadic and creative relationship to language and experience that is in distinct contrast to the deathly exile of the 'univers concentrationnaire', where language and representation are in the process of collapse. This nomadic relationship is illustrated by the use of different languages in the texts and the creative translational play between these languages. For example, in L'Écriture ou la vie, the narrator observes that he has not really survived Buchenwald but rather has had the experience of passing through death ( $E V$, p. I 49). Yet, he reflects, neither English nor French has a single word to express life as an experience of itself, whereas in German and Spanish respectively, the words 'Erlebnis' and 'vivencia' express this idea ( $E V$, p. I49). This reflection is inevitably rather ironic given that Semprun records his Buchenwald experience in French-it is as if the narrator is performing his own absence, abstracting himself from an experience he cannot possess. Ultimately, this is perhaps appropriate because narratorial self-dissolution can stage a testimonial practice in which, as he observes in L'Écriture ou la vie, he can 'parler au nom des naufragés. Parler en leur nom, dans leur silence, pour leur rendre la parole’ (ÉV, p. I49).

In Adieu, it is the silenced other within the self that the francophone narrator has to face in the representation of his self-reconstruction in exile. As Julia Kristeva has observed, the situation of the polyglot is silence: 'ainsi, entre deux langues, votre élément est-il le silence. A force de se dire de diverses manières tout aussi banales, tout aussi approximatives, ça ne se dit plus. [. . . Ne rien dire,

${ }^{8}$ This Way for the Gas, Ladies and Gentlemen (Harmondsworth: Penguin, I 976), p. 35.

49 The Drowned, p. 79.

$5 \circ$ Ibid., p. 76.

${ }^{5}$ For an early discussion of the impact of Nazism on the German language, see George Steiner's essay 'The Hollow Miracle' in Language and Silence: Essays I958-I966 (London: Faber and Faber, I 967$)$, pp. I I $7-32$. 
rien n'est à dire, rien n'est dicible. ${ }^{52}$ Similarly, in his Buchenwald writings the narrator has to face his own alterity and silence both as past and as present states. As Semprun states in a dialogue with Elie Wiesel (also a former Buchenwald prisoner): 'C'est une écriture inépuisable, à la fois impossible et inépuisable. On ne peut pas dire, mais on n'aura jamais tout dit. ${ }^{53}$ This self-silencing or loss of voice is further evident in the extensive citations and intertextual references in his writing. This self-dissolution occurs through ventriloquismas if he can be present only by speaking the words and thoughts of another. In addition to exhibiting Semprun's considerable cultural capital (albeit largely patriarchal), this ventriloquism has ethical implications because it becomes a way of performing a dissolution of the self-other binary and the narrator's absence and alterity in a 'devoir de mémoire' to the other's voice. In this way Semprun performs the 'je' in exile, illustrating Edmond Jabès's exploration of 'étrangeté' in Un étranger avec, sous le bras, un livre de petit format ( I 989). In this generically unclassifiable text, Jabès explores the alterity of ' $\mathrm{je}$ ' in a collection of dialogues and fragments. 'L'étranger' is 'je', yet a 'je' who effaces himself as he speaks: “Je” n'est pas l'autre. Il est “Je”. Creuser ce “Je”, telle est la tâche qui nous incombe. ${ }^{54}$ Within the terms of Jabès's exploration it is necessary to 'accorder droit de cité à la nouvelle appellation de l'étranger-l'étrange $\mathcal{F} e$ ' ${ }^{55}$ However, Gary D. Mole argues that for Jabès 'l'étrange $\mathcal{F} e$ ' is not fixed as a stable concept because the 'je' is identified with the ceaselessly shifting terms of étranger-writer-Jew-nomad-sage. ${ }^{56}$ Hence the étranger-for our purposes here Semprun as estranged writer in exile and Buchenwald revenant-ultimately escapes definition, disappears in his self-writing in an act of temporary selfdispossession and hospitality to the other. In L'Écriture ou la vie, the narrator articulates clearly his own sense of this self-dispossession in writing:

L'écriture, si elle prétend être davantage qu'un jeu, ou un enjeu, n'est qu'un long, interminable travail d'ascèse, une façon de se déprendre de soi en prenant sur soi: en devenant soi-même parce qu'on aura reconnu, mis au monde l'autre qu'on est toujours. (EV, p. 304)

In addition to the lost mother and women by extension functioning in Semprun's texts as 'l'autre absolu', who else-apart from himself-is Semprun's other? ${ }^{57}$ His dispersed voice in exile testifies for the abject other or 'musulman' whom he meets in Buchenwald. The abject other, cast as double and as surrogate corpse, appears frequently in Semprun's writing, functioning as the other (self) who enables his survival. An early example is 'le gars de Sémur' in Le Grand Voyage who acts as Gérard's interlocutor until his death on arrival at Buchenwald, at which point Gérard leaves him in the cattle truck in an act of mutual desertion $(G V$, pp. 256-57). In Le Mort qu'il faut, the narrator

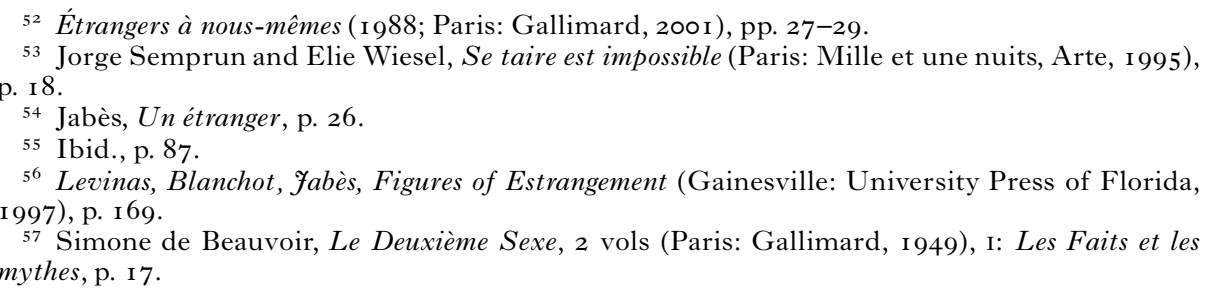


emphasizes his similarity to the 'musulman' to whom he is linked by a 'destin quasiment ontologique' and whose name he will take to facilitate his own survival (MF, p. 42):

Ce mort vivant était un jeune frère, mon double peut-être, mon Doppelgänger: un autre moi-même ou moi-même en tant qu'autre. C'était l'altérité reconnue, l'identité existentielle perçue comme possibilité d'être autre, précisément, qui nous rendait si proches. $(M F$, p. 43$)$

The other who dies for Semprun and as Semprun in the sanatorium at Buchenwald in an administrative exchange is immortalized anonymously on the title-page as 'le mort qu'il faut' below the name of Jorge Semprun. Intratextually he is identified as 'François', the universal Frenchman whom in Adieu the young exiled Jorge sought to become. In Buchenwald, as depicted in Le Mort qu'il faut, when Semprun first meets his 'musulman' double, he tries to engage him in conversation but receives no reply other than a gesture asking for cigarettes. On subsequent meetings, the 'musulman' remains silent to the point that the narrator observes: 'En somme, je le payais en tabac pour qu'il m'écoute lui raconter ma vie' $(M F$, p. 44$)$. In this context, autothanatography acts as a quest for survival by perpetual suicide as one entrusts what one was to the hospitality of the dying other, who cannot speak, and who makes the life recounted a secret unto the grave. In Semprun's experience of exile, as in his experience of Buchenwald, aspects of the other within the self are abjected and subsequently entrusted or projected onto others, such as the 'musulman' as noted above.

As Simone de Beauvoir argues in relation to gender and subjectivity in Le Deuxième Sexe, alterity is not a homogeneous category: others are not the same as each other. ${ }^{5}$ Alterity can be viewed rather as a continuum across which some have further to travel to accede to subjecthood, according to the subject's mode of interface with contingently prevailing ideologies. Echoing Beauvoir's celebrated dictum 'On ne naît pas femme, on le devient', Jabès asserts in $U n$ étranger, 'On ne naît pas étranger. On le devient, à mesure que l'on s'affirme. ${ }^{59}$ In this instance, the writer is Jew, nomad, and outsider par excellence for Jabès, an eternal pariah in the process of revealing her own strangeness to herself. It is only by engaging with one's own strangeness that one is able to encounter the radical alterity of the other, as Mole argues in relation to Jabès: 'The face of Jabès's other is what reveals my own alterity to myself, and to be myself is to be alone. It is my unique, positive difference that guarantees the irreducible difference of the other.' ${ }^{\text {, }}$

To conclude, I have argued that there is a clear link between Semprun's representation of exile and loss in Adieu, vive clarté . . . and his recent Buchenwaldrelated texts, L'Écriture ou la vie and Le Mort qu'il faut. All of these texts mobilize strategies of multilingualism, intertextuality, circular and fragmentary narrative patterns in a creative reworking of autobiographical writing. In

\footnotetext{
${ }^{8}$ Ibid., pp. I 7-I 9

59 Ibid., II: L'Expérience vécue, p. I 3 ; Un étranger, p. 25.

6o Levinas, Blanchot, Fabès, p. I 74.
} 
so doing, they evoke the trauma of exile and loss by speaking for the absent other and evoking the alterity of the self. However, if language is a means of responding to the 'fall' constituted by exile and subsequent internment in Buchenwald, it is none the less deployed by a Semprunian narrating subject predicated on the patriarchal positioning of woman as absolute other in which the feminine is ultimately abjected. Consequently, Semprun's autothanatographical project remains circumscribed by a melancholic patriarchal masculinity which fails to let the $\mathrm{m} /$ other go in its inexhaustible quest to write Buchenwald. 